DOI: http://doi.org/10.21698/simi.2017.0033

\title{
IMPACT OF ANTIBIOTICS OF ANTHROPOGENIC ORIGIN ON BACTERIAL SOIL COMMUNITIES IN AGRICULTURAL ECOSYSTEMS. REVIEW
}

\author{
Elena Radu ${ }^{1,2}$, Markus Woegerbauer ${ }^{2}$, Markus Oismüller ${ }^{3}$, Norbert Kreuzinger ${ }^{1}$ \\ ${ }^{1}$ Institute for Water Quality, Resources and Waste Management, University of Technology, \\ Karlsplatz 13/226, A-1040 Vienna, Austria, eradu@iwag.tuwien.ac.at, \\ norbkreu@iwag.tuwien.ac.at \\ ${ }^{2}$ AGES - Austrian Agency for Health and Food Safety, Spargelfeldstraße 191, A-1220 Vienna, \\ Austria, markus.woegerbauer@ages.at \\ ${ }^{3}$ Centre for Water Resource Systems, TU Wien, Karlsplatz 13, A-1040 Vienna, Austria, \\ oismueller@waterresources.at
}

\begin{abstract}
Soil is considered to be the most diverse microbiological ecosystem on Earth. Microbial soil biodiversity is substantially influenced by animal husbandry, intensive agricultural practices and soil cultivation (tillage, crop rotation, irrigation, organic and inorganic fertilization, application of pesticides etc.). Soil mismanagement represents a worldwide topic that impairs natural ecosystem sustainability as a first consequence. In order to understand and correctly apply soil management practices a deep insight in ecological processes is necessary.

Soil microbiota have a great impact on both natural processes (biogeochemical cycles) as well as various other aspects that could influence human health and the quality of life (micro- or macro-contaminants, pharmaceuticals, fertilizers, phytosanitary products). Pharmaceuticals, especially antibiotics are intensively used in animal husbandry either as therapeutic agents or for prophylactic measures. Antibiotics of microbial, semi-synthetic or synthetic origin impact the metabolism of bacteria: at subinhibitory concentrations they act as hormetic intercellular messengers stimulating gene expression. Higher amounts have bacteriostatic or bactericidal effects according to their mode of action. Both result in a profound modulation of bacterial community structure and biodiversity by boosting genotypic and phenotypic variability and induction of antibiotic resistance. They also pose an indirect effect on the communities (generating different genotypic and phenotypic variability such as antibiotic resistance). Agricultural management practices like application of organic fertilizers (e.g. manure) expose soil microbiota to a variety of hazardous agents of anthropogenic origin including antibiotics, antibiotic resistant bacteria and antibiotic resistance genes which interact with the indigenous soil resistome.

This paper describes the impact of human land-use, especially the ecological effects of antibiotics on natural ecosystems and the increase of antibiotic resistance in soil communities.
\end{abstract}

Keywords: antibiotics, antibiotic resistance genes, natural ecosystems, soil microbiota, soil management practices

\section{Introduction}

Soil is considered to be the most diverse microbiological ecosystem on Earth. Soil microbiota plays a key role in the ecosystem sustainability and stability. Soil 


\section{INTERNATIONAL SYMPOSIUM "THE ENVIRONMENT AND THE INDUSTRY", SIMI 2017, PROCEEDINGS BOOK}

microorganisms take part in different biogeochemical processes such as nitrogen and carbon cycling and they act also as mediator in several ecological processes such as bioremediation, pollution control, soil health and fertility (Paul 2007). Soil microcosms present a broad microbial biodiversity closely related with abiotic factors (soil types, agriculture practices, temperature, $\mathrm{pH}$, moisture, selective pressure factors - metals, biocides, antibiotics) and biotic factors (plant types, soil microbial communities, other relationships between soil inhabitants) (O'Brien 2002; Aminov 2011; Pal et al. 2015).

Approximatively $65 \%$ of total soil microorganisms are found in the top $25 \mathrm{~cm}$ of soil, with an abundance of Gram negative bacteria at the soil surface and Gram-positive bacteria residing in deeper layers (Paul 2007). Microbial biodiversity and activity is higher on top of the soil due to the pores which influence the availability of water and energy sources. Usually, soil communities are attached to different soil constituents such as humic acids, clays, soil organic matter, due to their negative charge and also for protection (Paul 2007).

Understanding the multifunctionality of ecosystems represents a difficult task due to multiple and complex interactions between soil microbiota and environmental factors such as land use, different soil/crops types and climate changes (Singer et al. 2016), but also due to competitive, pathogenic or mutualistic relationships between the involved organisms. Agricultural management practices have a great impact on soil microbiota due to the release of antibiotics, metals and other compounds like pesticides/biocides which act as selective pressure factors and contribute to the emergence, maintenance and spread of antimicrobial resistance in the environment (Hölzel et al. 2012; Bender et al. 2016). Land use intensification, such as application of different pesticides/biocides, low plant diversity and intensive soil tillage, have been shown to have a negative impact on soil microorganisms. Soil mismanagement represents a worldwide topic that impairs natural ecosystem sustainability as a first consequence (Singer et al. 2016).

\section{Ecological effects of antibiotics on natural ecosystems}

Animal husbandry and intensive agriculture practices influence particularly the microbial soil biodiversity and also contribute to different environmental problems related with human health and the quality of life. Pharmaceuticals, especially antibiotics are intensively used in animal husbandry either as therapeutic agents or for prophylactic measures (Kummerer 2009a; Tasho \& Cho 2016). Land spreading of animal manure releases in the environment a large variety of antibiotics (A), antibiotic resistant bacteria (ARB) and a vast variety of antibiotic resistance genes (ARGs) into the environment (Bender et al. 2016).

Antibiotics of microbial, semi-synthetic or synthetic origin impact the metabolism of bacteria: at subinhibitory concentrations they act as hermetic intercellular messengers stimulating gene expression (Davies et al. 2006). Higher amounts have bacteriostatic or bactericidal effects according to their mode of action. Both result in a profound modulation of bacterial community structure and biodiversity by boosting genotypic and phenotypic variability and induction of antibiotic resistance (Gothwal \& Sashidhar 2014).

The origin of antibiotics in natural environments such as soil or water is related especially with their fate: firstly, urban wastewater treatment plants (UWWTPs) are considered to be one of the most important hot-spots of the dissemination of A, ARB 


\section{INTERNATIONAL SYMPOSIUM "THE ENVIRONMENT AND THE INDUSTRY", SIMI 2017, PROCEEDINGS BOOK}

and ARGs (Rizzo et al. 2013) - a large part of antibiotics that are consumed by humans are excreted in urine and faeces and thus enter UWWTPs. Reclaimed water (WWTP effluent) is used in many countries for irrigation purposes and thus A, ARB and ARGs present in this matrix are introduced into soil habitants because wastewater treatment processes only inefficiently remove these substances (Durso \& Cook 2014). Also, ground and surface waters (which could receive drainage water from contaminated soils) used for animals or for irrigation are important sources of ARB and ARGs. Another way is represented by land application of sludge/biosolids that originate from UWWTPs. It is estimated that in Europe, 37\% of biosolids are land applied (Kinney et al. 2008). Secondly, another important source of antibiotics is animal husbandry. Antibiotics which are used either as therapeutic agents or for prophylactic measures are excreted in urine and faeces and subsequently used as natural fertilizers and are deposited in agricultural soils. Manure management plays a key role in assessing the risks of soil contamination with ARB and ARGs and thus the faeces that come from swine farms are continuously monitored (Haley et al. 2012). Also, grazing animals could contribute to the spread of antibiotic resistance in soil. From soil the A, ARB and ARGs get into the fresh water (groundwater, surface water, like streams, rivers, sea) or in different crops/vegetables and thus could adversely impact human health (Singer et al. 2016).

\section{Antibiotics persistence and antibiotics resistance in agricultural ecosystems}

The negative effects of antibiotics in natural environments such as soil could be divided in two important directions: on the one hand, they act on the development of antimicrobial resistance and/or on the other hand they alter the natural ecological functions of soil.

The most frequent antibiotics found in animal faces are represented by oxytetracycline, doxycyclin and sulfadiazine, followed by tetracycline, tylosin and lincomycin (Berendsen et al. 2015). In contrast, the antibiotics found in sludge are norfloxacin, ofloxacin, ciprofloxacin, trimethoprim, sulfamethoxazole and doxycycline (McClellan \& Halden 2010; Clarke \& Smith 2011). Studies have shown that different residual antibiotics are frequently detected in activated sludge, urban biosolids (Zhang \& Li 2011), animal manure, sewage sludge, sediments (Kemper 2008; Yang et al. 2010b), wastewater, reclaimed water, surface water or groundwater (Renew \& Huang 2004; Gulkowska et al. 2007).

The persistence of antibiotics in soil microcosms is influenced mainly by temperature (Gavalchin \& Katz 1994; Winckler \& Grafe 2001), soil type (Marengo et al. 1997), pH (Gilbertson et al. 1990), adsorption affinity (Tolls 2001; Boxall et al. 2004), photodegradation (Kummerer 2009a, Knapp et al. 2005), biodegradation (Li \& Zhang 2010), oxidation (Adams et al. 2002). Also, the excretion rate (Jjemba 2002; Zuccato et al. 2001) and the half-life of the antibiotics (Gavalchin \& Katz 1994; Weerasinghe $\&$ Towner 1997) play a key role in the persistence of these antimicrobials in agricultural ecosystems. The adsorption of the antibiotics in soil environments is influenced by soil pH (Basakcilardan-Kabakci et al. 2007) and soil clay content (Cermak et al. 2008). Different antibiotic classes have different adsorption properties in soil environments (Wang \& Wang 2015).

The evolution of antimicrobial resistance is related to both long term exposure to low doses as well as short term exposure to high doses of antibiotics, genetic variation and horizontal transfer of antibiotic resistance genes (HGT) (Martinez 2009; Tasho \& Cho 


\section{INTERNATIONAL SYMPOSIUM "THE ENVIRONMENT AND THE INDUSTRY", SIMI 2017, PROCEEDINGS BOOK}

2016). The dissemination of ARGs in the natural environments is related with horizontal gene transfer (Williams-Nguyen et al. 2016; von Wintersdorff et al. 2016). Antimicrobial resistance acquired due to horizontal gene transfer can occur through different mechanisms such as conjugation (cell-to-cell contact), transduction (HGT mediated by phages), and transformation (uptake of extracellular DNA) (WilliamsNguyen et al. 2016). Soil microcosms offer good conditions for HGT due to the great microbial diversity, high cell densities, the persistence of extracellular DNA and also by the presence of different ARGs located on mobile genetic elements (Levy-Booth et al. 2007; Pietramellara et al. 2009).

The pesticides/biocides that are used in agriculture purposes act as selective pressure factors for the selection of antibiotic resistance (European Commission 2009; Webber et al. 2015; Buffet-Bataillon et al. 2016). In Europe, the use of biocides in veterinary settings has intensely increased between 1992 and 2007 by 40\% (Sattar et al. 2007). Nowadays, both the use of antimicrobials as well as biocides in veterinary purposes is strictly regulated by different guidelines (Guidelines 2015/C 299/04; Regulation 528/2012). Different antibiotic resistance mechanisms are common for pesticides/biocides and antibiotics; thus, they allow the acquisition of antibiotics resistance genes which enable higher tolerance for different bacteria strains (Russell 2003). The fate and the development of antibiotic resistance in agricultural soils due to the intensive use of the veterinary antibiotics as therapy, disease prevention and control, and growth promotion (National Committee for Clinically Laboratory Standards 2002) have been reviewed previously by different researchers (Jechalke et al. 2014, 2015; Kummerer 2009a, 2009b; Landers et al. 2012; Du \& Liu 2012; Ashbolt et al. 2013). The researchers highlight the importance of antibiotic usage in subinhibitory concentrations (veterinary purposes) and how the applied manure affects the signaling and maintenance of regulatory networks of soil bacteria communities. Also, it is important to take into account the selective pressure which could act on the environment resistome and also to identify and describe the rates of HGT in environmental hot-spots. In order to minimize antibiotic resistance, the European Union has banned the use of antibiotics as growth promoters since January $1^{\text {st }} 2006$ (Kemper 2008; Grenni 2017; Regulation 1831/2003/EC).

\section{The effects of antibiotics present in soil on human health}

World Health Organization (WHO) classified the drugs for animal use (antibiotics) in three important categories: critical drugs, highly important drugs and important drugs (WHO Critically important antimicrobials for human medicine. $5^{\text {th }}$ revision 2016). Most of the critical drugs are used frequently in cattle, swine and poultry farms. Not only is the type of the antibiotic important in human health risk assessment, but also the spectrum, mode of action and concentration. For each antibiotic, there could be not only one gene that encode it, but several genes that code for resistance, so it is also important to know how many genes are involved in resistance and monitor all of them (Ibekwe et al. 2011; Durso et al. 2011; Frye et al. 2011).

WHO presents the implications of antibiotic resistance for human health as being a serious problem - "associated with more frequent and longer hospitalisation, longer illness, a higher risk of invasive infection and a twofold increase in the risk of death ..." (WHO, Tackling antibiotic resistance from a food safety perspective in Europe, 2011). In order to diminish the usage of antibiotics, it is necessary to implement specific conditions such as publish clear policies for the use of antibiotics (especially 


\section{INTERNATIONAL SYMPOSIUM "THE ENVIRONMENT AND THE INDUSTRY", SIMI 2017, PROCEEDINGS BOOK}

for prophylactic measures), actively measure usage levels of antibiotics (especially for critical drugs) and report different situations of antimicrobial resistance (data bases).

In order to evaluate the benefits and risks of the presence of antibiotics in agroecosystems, especially because the dissemination of antimicrobial resistance in soil could affect human health through the food chain, soil, water, insects, dust and animals (Phillips et al. 2004; Landers et al. 2012), it is necessary to improve our understanding of the ecology and evolution of antibiotic resistance and its relationship with indigenous environmental bacteria, ARG and HGT (Święciło \& Zych-Wężyk 2013; D`Costa et al. 2007).

\section{Conclusions and future perspectives}

This paper describes the complexity and diversity of the antibiotic resistance in natural ecosystems (influenced by biotic and abiotic factors) and how soil mismanagement practices could act as mediators in the increase of environmental levels of antimicrobials.

The available data on the dynamics of ARB and ARGs in soil environments in response to the misuse of antibiotics from anthropogenic resources and to the increasing application of certain pesticides which affect bacterial population structure highlight how little we know regarding the impact of these compounds on soil microbial communities. Additional research focusing on the ecological impact of pharmaceuticals and pesticides used in agriculture or animal husbandry on natural environments like soil and water is necessary and will provide new insights for a better understanding of agricultural management practices and the interactions between antimicrobials and resistance towards them.

\section{Acknowledgements}

"The work presented in this paper is part of a project that has received funding from the European Union's Horizon 2020 research and innovation programme under the Marie Skłodowska-Curie grant agreement No 675530".

The authors declare that the research was conducted in the absence of any commercial or financial relationships that could be constructed as a potential conflict of interest.

Abbreviations: A - antibiotics; ARB - antibiotic resistant bacteria; ARGs - antibiotic resistance genes; HGT - horizontal gene transfer; WHO - World Health Organization; UWWTP - urban wastewater treatment plants; DNA - deoxyribonucleic acid.

\section{References}

Adams, C, Asce, M, Want, Y, Loftin, K \& Meyer, M 2002, 'Removal of Antibiotics from Surface and Distilled Water in Conventional Water Treatment Processes', Journal of Environmental Engineering, vol. 128, no. 3, pp. 253-260.

Aminov, RI 2011, 'Horizontal gene exchange in environmental microbiota', Frontiers in Microbiology, vol. 2, art. 158, pp 1-19.

Ashbolt, NJ, Amezquita, A, Backhaus, T, Borriello, P, Brandt, KK, Collignon, P, Coors, A, Finley, R, Gaze WH, Heberer, T, Lawrence, JR, Larsson, DG, McEwen, SA, Ryan, JJ, Schönfeld, J, Silley, P, Snape, JR, Van den Eede, C \& Topp, E 2013, 'Human health risk assessment (HHRA) for environmental development and transfer of antibiotic resistance', Environmental Health Perspectives, vol. 121, no. 9, pp. 993-1001. 


\section{INTERNATIONAL SYMPOSIUM "THE ENVIRONMENT AND THE INDUSTRY", SIMI 2017, PROCEEDINGS BOOK}

Basakcilardan-Kabakci, S, Thompson, A, Cartmell, E \& Le Corre, K 2007, 'Adsorption and precipitation of tetracycline with struvite', Water Environment Research: a research publication of the Water Environment Federation, vol. 79, no. 13 , pp. 2551-2556.

Bender, SF, Wagg, C \& van der Heijden, MGA 2016, `An Underground Revolution: Biodiversity and Soil Ecological Engineering for Agricultural Sustainability', Trends in Ecology \& Evolution, vol. 31, no. 6, pp. 440-452.

Berendsen, BJA, Wegh, RS, Memelink, J, Zuidema, T \& Stolker, LAM 2015, 'The analysis of animal faeces as a tool to monitor antibiotic usage`, Talanta, vol. 132 , pp. $258-268$.

Boxall, ABA, Fogg, LA, Blackwell, PA, Kay, P, Pemberton, EJ \& Croxford, A 2004, 'Veterinary medicines in the environment', Reviews of Environmental Contamination and Toxicology, pp. 1-91.

Buffet-Bataillon, S, Tattevin, P, Maillard, JY, Bonnaure-Mallet, M \& JolivetGougeon, A 2016, `Efflux pump induction by quaternary ammonium compounds and fluoroquinolone resistance in bacteria, Future Microbiology, vol. 11, no.1, pp. 8192.

Clarke, BO \& Smith, SR 2011, 'Review of "emerging" organic contaminants in biosolids and assessment of international research priorities for the agricultural use of biosolids`, Environment International, vol. 37, pp. 226-247.

Cermak, L, Kopecky, J, Novotna, J, Omelka, M, Parkhomenko, N, Plhackova, K \& Sagova-Mareckova 2008, 'Bacterial communities of two contrasting soils reacted differently to lincomycin treatment', Applied Soil Ecology, vol. 40, pp. 348-358.

Davies, J, Spiegelman, GB \& Yim, G 2006, 'The world of subinhibitory antibiotic concentrations`, Current Opinion in Microbiology, vol. 9, no. 5, pp. 445-453.

D'Costa, VM, Griffiths, E \& Wright GD 2007, 'Expanding the soil antibiotic resistome: exploring environmental diversity', Current Opinion in Microbiology, vol. 10, pp. 481-489.

Du, LF \& Liu, WK 2012, 'Occurrence, fate, and ecotoxicity of antibiotics in agroecosystems. A review`, Agronomy for Sustainable Development, vol. 32, no. 2, pp. 309-327.

Durso, LM \& Cook, KL 2014, 'Impacts of antibiotic use in agriculture: what are the benefits and risks?', Current Opinion in Microbiology, vol. 19, pp. 37-44.

Durso, LM, Harhay, GP, Bono, JL \& Smith, TPL 2011, 'Virulence- associated and antibiotic resistance genes of microbial populations in cattle feces analyzed using a metagenomic approach', Journal of Microbiological Methods, vol. 84, no.2, pp. 278-282.

European Commission 2009, Scientific Committee on Emerging and Newly Identified Health Risks (SCENIHR). Assessment of the Antibiotic Resistance Effects of Biocides. Available from: http://ec.europa.eu/health/archive/ph_risk/committees/04_scenihr/docs/scenihr _o_021.pdf [19 January 2009].

Frye, JG, Lindsey, RL, Meinersmann, RJ, Berrang, ME, Jackson, CR, Englen, MD, Turpin, JB \& Fedorka-Cray, PJ 2011, 'Related antimicrobial resistance genes detected in different bacterial species co-isolated from swine fecal samples', Foodborne Pathogens and Disease, vol. 8, no.6, pp. 663-679. 


\section{INTERNATIONAL SYMPOSIUM "THE ENVIRONMENT AND THE INDUSTRY", SIMI 2017, PROCEEDINGS BOOK}

Gavalchin, J \& Katz, SE 1994, 'The persistence of fecal-borne antibiotics in soil', Journal of AOAC International, vol. 77, pp. 481-485.

Gilbertson, TJ, Hornish, RE, Jaglan, PS, Koshy, KT, Nappier, JL, Stahl, GL, Cazers, AR, Nappier, JM \& Kubicek, MF 1990, 'Environmental fate of ceftiofur sodium, a cephalosporin antibiotic: role of animal excreta in its decomposition', Journal of Agricultural and Food Chemistry, vol. 38, no 3, pp. 890-894.

Gothwal, R \& Shashidhar, T 2014, 'Antibiotic Pollution in the Environment: A Review`, Clean - Soil, Air, Water, vol. 42, no. 9999, pp. 1-11.

Grenni, P, Ancona, V \& Caracciolo, AB 2017, 'Ecological effects of antibiotics on natural ecosystems: A review`, Microchemical Journal, doi: 10.1016/j.microc.2017.02.006.

Guidelines for the prudent use of antimicrobials in veterinary medicine - 2015/C 299/04.

Gulkowska, A, He, YH, So, MK, Yeung, LW, Leung, HW, Giesy, JP, Lam, PK, Martin, M \& Richardson, BJ 2007, 'The occurrence of selected antibiotics in Hong Kong coastal waters`, Marine Pollution Bulletin, vol. 54 no. 8, pp. 12871293.

Haley CA, Dargatz DA, Bush, EJ, Erdman, MM \& Feodorka-Cray, PJ 2012, 'Salmonella prevalence and antimicrobial susceptibility from the National Animal Health Monitoring System swine 2000 and 2006 studies`, Journal of Food Protection, vol. 75, no.3, pp 428-436.

Hölzel, CS, Müller, C, Harms, KS, Mikolajewski, S, Schäfer, S, Schwaiger, K \& Bauer, J 2012, 'Heavy metals in liquid pig manure in light of bacterial antimicrobial resistance', Environmental Research, vol. 113, pp. 21-27.

Ibekwe, AM, Murinda, SE \& Graves, AK 2011, 'Genetic diversity and antimicrobial resistance of Escherichia coli from human and animal sources uncovers multiple resistances from human sources`, PLoS One, vol.6, no.6, e20819.

Jechalke, S, Cook, KL \& Smalla, K 2015, Approaches to Assess the Effects and Risks of Veterinary Antibiotics Applied with Manure to Soil, Intech, Croatia. Available from: https:/www.intechopen.com/books/antimicrobial-resistancean-open-challenge/approaches-to-assess-the-effects-and-risks-of-veterinaryantibiotics-applied-with-manure-to-soil. [26 November 2016].

Jechalke, S, Heuer, H, Siemens, J, Amelung, W \& Smalla, K 2014, 'Fate and effects of veterinary antibiotics in soil, Trends in Microbiology, vol. 22, no. 9, pp. 536-545.

Jjemba, P 2002, 'The potential impact of veterinary and human therapeutic agents in manure and biosolids on plants grown on arable land: a review', Agriculture, Ecosystems \& Environment, vol. 93, pp. 267-278.

Kemper, N 2008, 'Veterinary antibiotics in the aquatic and terrestrial environment', Ecological Indicators, vol. 8, pp. 1-13.

Kinney, CA, Furlong, ET, Kolpin, DW, Burkhardt, MR, Zaugg, SD, Werner, SL, Bossio, JP \& Benotti, MJ 2008, 'Bioaccumulation of pharmaceuticals and other anthropogenic waste indicators in earthworms from agricultural soil amended with biosolid or swine manure', Environmental Science \& Technology, vol. 42, pp. 1863-1870.

Knapp, CW, Cardoza, LA, Hawes, JN, Wellington, EM, Larive, CK \& Graham, DW 2005, 'Fate and effects of enrofloxacin in aquatic systems under different light conditions`, Environmental Science \& Technology, vol. 39, no. 23, pp. 9140-9146. 


\section{INTERNATIONAL SYMPOSIUM "THE ENVIRONMENT AND THE INDUSTRY", SIMI 2017, PROCEEDINGS BOOK}

Kummerer, K 2009a, 'Antibiotics in the aquatic environment - a review - part I, Chemosphere, vol. 75, pp. 417-434.

Kummerer, K 2009b, 'Antibiotics in the aquatic environment - a review - part I, Chemosphere, vol. 75, pp. 435-441.

Landers, TF, Cohen, B, Wittum, TE, Larson, EL 2012, 'A review of antibiotic use in food animals: perspective, policy, and potential', Public Health Reports, vol. 127, pp. 4-22.

Levy-Booth, DJ, Campbell, RG, Gulden, RH, Hart, MM, Powell, JR, Klironomos, JN, Pauls, KP, Swanton, CJ, Trevors, JT \& Dunfield, KE 2007, 'Cycling of extracellular DNA in the soil environment', Soil Biology and Biochemistry, vol. 39, pp. 2977-2991.

Li, B \& Zhang, T 2010, 'Biodegradation and adsorption of antibiotics in the activated sludge process`, Environmental Science \& Technology, vol. 44, pp. 3468-3473.

Marengo, JR, Kok, RA, O`Brien, K, Velagaleti, RR \& Stamm, JM 1997, `Aerobic biodegradation of (14C)-Sarafloxacin hydrochloride in soil, Environmental Toxicology and Chemistry, vol. 16, no.3, pp. 462-471.

Martinez, JL 2009, 'Environmental pollution by antibiotics and by antibiotic resistance determinants`, Environmental Pollution., vol. 157, no.11, pp. 28932902.

McClellan, K \& Halden, RU 2010, 'Pharmaceuticals and personal care products in archived U.S. biosolids from the 2001 EPA national sewage sludge survey', Water Research, vol. 44, no. 2, pp. 658-668.

O'Brien TF 2002, 'Emergence, spread, and environmental effect of antimicrobial resistance: how use of an antimicrobial anywhere can increase resistance to any antimicrobial anywhere else', Clinical Infectious Diseases: an official publication of the Infectious Diseases Society of America, vol. 34, no. 3, pp. S78-S84.

Pal, C, Bengtsson-Palme, J, Kristiansson, E \& Larsson DGJ 2015, 'Co-occurrence of resistance genes to antibiotics, biocides and metals reveals novel insights into their co-selection potential, BMC Genomics, vol. 16, pp. 964-978.

Paul, EA 2007, Soil Microbiology, Ecology and Biochemistry, $3^{\text {rd }}$ Edition, Elsevier Inc., USA.

Phillips, I, Casewell, M, Cox, T, De Groot, B, Friis, C, Jones, R, Nightingale, C, Preston, R \& Waddell, J 2004, 'Does the use of antibiotics in food animals pose a risk to human health? A critical review of published data, The Journal of Antimicrobial Chemotherapy, vol. 53, no.1, pp. 28-52.

Pietramellara, G, Ascher, J, Borgogni, F, Ceccherini, MT, Guerri, G \& Nannipieri, P 2009, 'Extracellular DNA in soil and sediment: Fate and ecological relevance', Biology and Fertility of Soils, vol. 45, no.3, pp. 219-235.

Regulation (EU) 528/2012 of the European parliament and of the council of 22 may 2012 concerning the making available on the market and use of biocidal products, Official Journal of the European Union, vol. 167, pp. 1-123.

Regulation 1831/2003/EC on additives for use in animal nutrition.

Renew, JE \& Huang, CH 2004, 'Simultaneous determination of fluoroquinolone, sulfonamide and trimethoprim antibiotics in wastewater using tandem solidphase extraction and liquid chromatography electrospray-mass spectrometry, Journal of Chromatography. A, vol. 1042, no. 1-2, pp. 113-121. 


\section{INTERNATIONAL SYMPOSIUM "THE ENVIRONMENT AND THE INDUSTRY", SIMI 2017, PROCEEDINGS BOOK}

Rizzo, L, Manaia, C, Merlin, C, Schwartz, T, Dagot, C, Ploy, MC, Michael, I \& FattaKassinos, D 2013, 'Urban wastewater treatment plants as hotspots for antibiotic resistant bacteria and genes spread into the environment: A review`, The Science and the Total Environment, vol. 447, pp. 345-360.

Russell, AD 2003, 'Biocide use and antibiotic resistance: the relevance of laboratory findings to clinical and environmental situations, The Lancet. Infectious Disease, vol. 3, no.12, pp. 794-803.

Sattar, SA, Tetro, JA \& Springthorpe, VS 2007, 'Effects of environmental chemicals and the host-pathogen relationship: are there any negative consequences for human health?", New Biocides Development, vol. 967, pp. 2-30.

Singer, AC, Shaw, H, Rhodes, V \& Hart A 2016, 'Review of antimicrobial resistance in the environment and its relevance to environmental regulators', Frontiers in Microbiology, vol. 7, no. 1728, pp 1-22.

Święciło, A \& Zych-Wężyk, I 2013, 'Bacterial stress response as an adaptation to life in a soil environment', Polish Journal of Environmental Studies, vol. 22, no. 6, pp. 1577-1587.

Tasho, RP \& Cho, JY 2016, 'Veterinary antibiotics in animal waste, its distribution in soil and uptake by plants: A review', The Science of the Total Environment, vol. 563-564, pp. 366-376.

Tolls, J 2001, 'Sorption of veterinary pharmaceuticals in soil: a review', Environmental Science and Technology, vol. 35, no. 17, pp. 3397-3406.

von Wintersdorff, CJH, Penders, J, van Niekerk, JM, Mills, ND, Majumder, S, van Alphen, LB, Savelkoul, PHM \& Wolffs, PFG 2016, 'Dissemination of antimicrobial resistance in microbial ecosystems through horizontal gene transfer", Frontiers in Microbiology, vol. 7, no. 173, pp.1-10.

Wang, S \& Wang, H 2015, 'Adsorption behaviour of antibiotic in soil environment: a critical review`, Frontiers of Environmental Science \& Engineering, vol. 9, no. 4 , pp. 565-574.

Webber, MA, Whitehead, RN, Mount, M, Loman, NJ, Pallen, MJ \& Piddock, LJ 2015, 'Parallel evolutionary pathways to antibiotic resistance selected by biocide exposure', The Journal of Antimicrobial Chemotherapy, vol. 70, no.8, pp. 2241-2248.

Weerasinghe, CA \& Towner, D 1997, `Aerobic biodegradation of virginiamycin in soil, Environmental Toxicology and Chemistry, vol. 16, no.9, pp. 1873-1876.

WHO 2017, Critically important antimicrobials for human medicine, $5^{\text {th }}$ revision 2016 , World Health Organization.

WHO 2011, Tackling antibiotic resistance from a food safety perspective in Europe, World Health Organization.

Williams-Nguyen, J, Sallach, JB, Bartelt-Hunt, S, Boxall, AB, Durso, LM, McLain, JE, Singer, RS, Snow, DD \& Zilles, JL 2016, 'Antibiotics and antibiotic resistance in agroecosystems: state of the science', Journal of Environmental Quality, vol. 45, no.2, pp. 394-406.

Winckler, C \& Grafe, A 2001, 'Use of veterinary drugs in intensive animal production: evidence for persistence of tetracyclines in pig slurry`, Journal of Soils \& Sediments, vol. 1, no.2, pp. 66-70.

Yang, JF, Ying, GG, Zhao, JL, Tao, R, Su, HC \& Chen, F 2010b, 'Simultaneous determination of four classes of antibiotics in sediments of the pearl rivers using 
RRLC-MS/MS`, The Science of the Total Environment, vol. 408, pp. 34243432 .

Zhang, T \& Li, B 2011, 'Occurrence, transformation, and fate of antibiotics in municipal wastewater treatment plants`, Critical Reviews in Environmental Science and Technology, vol. 41, no. 11, pp. 951-998.

Zuccato, E, Bagnati, R, Fioretti, F, Natangelo, M., Calamari, D \& Fanelli, R 2001, 'Environmental loads and detection of pharmaceuticals in Italy', Pharmaceuticals in the Environment, pp. 19-27. 